\title{
Sustainable Development of the Marine Leisure Industry Along the Indian Coastline
}

\author{
Madhumita Kothari , S. Poongavanam
}

\begin{abstract}
Marine leisure organisation has the intrinsic capability to land up one of the tremendous supporters of the GDP of India each time created in a maintainable way with appropriate control faster rather than later. The perfect seashores of India which can be long and massive, a few being hard and motorable throughout low tide may be domestic to distinct water sports activities activities with worldwide measures. The Cruise organization comprehensive of beach the front transportation and circulate travels may be a noteworthy wellspring of amusement for household and remote visitors. Beacon the tour enterprise with its associated tools is likewise being created through the legislature. The submerged social legacy locales at Dwarka, Mahabalipuram, Rameshwaram and Poompuhar can be created as vacationer visit territories through submarines like that created in Mauritius. The marine the tour business enterprise may be coordinated with the voyage thru the rich social legacy of Indian land mass.

The legislature in accordance with the Tourism association and practical development desires have strategized extraordinary hobby intends to present a noteworthy elevate to the marine relaxation employer. With the brand new authorities the interest plans must be actualized to in reality assist the business enterprise that might enlarge to be a noteworthy supporter of the GDP of the country.
\end{abstract}

Key Words: Sustainable development, Coastal shipping, River cruise, Governance, Pollution \& BIMSTEC

\section{INTRODUCTION}

A a fulfillment overview of the cutting-edge framework is fundamental to recognize the pertinent problems that have an impact on the commercial enterprise as on date. Properlybeing and safety being an before the entirety sight impinging problem ought to be tended to with lucidity and profundity. Territorial participation can be improved inner BIMSTEC and Sagarmala development ventures to provide a noteworthy push to the marine relaxation company of India.

\section{Creation}

The tour corporation is a whole usage of handy property along with regular, human, social, verifiable and infrastructural. The tourist is a shopper of products and recipient of administrations. Along the ones traces, the travel business enterprise can bolster monetary development of both the community community and the economic system of a country, through take advantage of close by and out of doors guests. This makes the travel corporation a noteworthy motor of economic improvement and a considerable wellspring of organization and out of doors trade profits in India. The overall dedication of the Tourism business company in India to the GDP is 6.Eight\%. Marine

Revised Manuscript Received on April 12, 2019.

Madhumita Kothari, AMET Business School, Chennai, Tamilnadu, India. India.

Dr. S. Poongavanam, AMET Business School, Chennai, Tamilnadu, pastime enterprise can also moreover construct the profits earnings of the Blue monetary system with a diffusion of at any fee three\% to the GDP.

India has a coastline of around $7517 \mathrm{kms}$ spreading over from West Bengal to Gujarat at the territory, the Andaman and Nicobar Islands and the Lakshwadeep Islands. The coastline of India is described with the resource of outstanding shores, beacons, lakes, waterway mouths, sanctuaries, exceptional locales, submerged social legacy, indigenous way of life and first rate geology.

Ongoing marine archeological research has represented that portions of the Indian shoreline at Dwarka, Gulf of Khambhat, Mahabalipuram, Poompuhar, Rameshwaram had city human enhancements that bypass back to 11600 years The submerged social legacy in those spots has exposed the vintage beach the front records of India that could form an inborn part of the marine rest industry. The Ministry of Tourism has the number one purpose of growing and inspiring the excursion corporation in India, looking ahead to the kingdom as an all climate visitor goal, advancing the adventure enterprise in a practical manner. This newsletter examinations the significance of marine the tour industry in India offering how best the economic employer may be created in a viable way increasing the GDP significantly.

\section{SUSTAINABLE MARINE TOURISM IN INDIA}

The 2002 country wide Tourism insurance of India identified the tour enterprise as a motor of economic improvement and imagined the department as a financial multiplier under the device of 'authorities-drove, personalissue decided and community welfare placed' and centered on the want to create the journey agency in an earth supportable manner. The rule of thumb of possible the tour agency became proposed as in advance of time table as 1988 with the resource of the sector Tourism organisation, with practical the tour business enterprise "conceived as prompting the board of all property so that financial, social and tasteful dreams can be happy while preserving up social respectability, important environmental procedures, herbal diverse range and lifestyles emotionally supportive networks". Reviewing past affirmations on the adventure corporation, as an example, the Manila statement on world the tour industry, the Hague statement and the Tourism invoice of Rights and tourist Code, the charter for practical the tour business enterprise recommended for the duration of the world convention on Sustainable Tourism, held in Lanzarotein 1995, underlined the need to build up a form of the journey business enterprise that meets both financial 
desires and herbal necessities, and regards now not just the social and physical shape of its purpose, but additionally the nearby populace.

Supportable the excursion company, which encompass ecotourism, can notably have an effect at the restoration and safety of the environments. Web page site visitors are beginning to cognizance on natural gauges and accreditations utilising not absolutely to goals and the adventure corporation framework yet additionally to hotels and the behavior of the journey enterprise and delivery administrators.

India is honored with various incredible beaches along each the west and east coast. Setting among them are Juhu and Chowpatty seashores in Mumbai, Baga, Candolim, Cavalossim, Anjuna beaches of Goa, Kovalam shoreline in Kerala, Marina coastline in Chennai, Vizag in Andhra Pradesh, Puri and Gopalpur beaches in Odisha, Digha and Mandarmoni seashores in West Bengal. These seashores are very loads grown, long and massive. Part of the seashores like Mandarmoni and Puri are difficult and motorable within the path of low tide. Safe water sports activities sports of worldwide norms may be supported with the aid of means of these shores with out hectic the shoreline eco framework.

Travels are one of the maximum effective and the quickest growing elements of the relaxation business spherical the sector. It's far brief growing as another appealing item. India with its big and adorable shoreline, virgin timberlands and undisturbed herbal islands, rich authentic and social legacy, can be a excellent tourist intention for voyage travelers. With the Indian economic system growing at an unfaltering tempo, white collar magnificence growing in range and frequently having expendable livelihoods which can be spent on enterprise wearing activities, Indians may want to likewise take on adventure handing over in a chief manner. The shoreline and inland conduits can probable boom cruise tourism, every international and domestic. To harness this, there can be a want to offer crucial infrastructural centers through ports in terms of berths, terminals and traveler/passenger facilities.

some other revolutionary marine tourism initiative with the resource of the use of the authorities is mild house tourism. There are almost a hundred ninety slight homes along the Indian coast and the surrounding areas offer opportunities for development of accommodations, motels, viewing galleries, journey sports activities, thematic eating place and allied tourism centers. The Directorate state-of-the-art of Lighthouses and moderate ships has identified 78 lighthouses, and adjacent regions spherical 8 lighthouses are being superior for tourism.

numerous underwater cultural ancient past websites had been determined with the aid of using marine archeologists at Poompuhar, Mahabalipuram, Rameshwaram and Dwarka. The government can expand submarine tourism as in Mauritius to put together visits to the ones underwater net websites. this may lure no longer just home travelers from India however moreover a huge variety of foreign tourists who could be pleased to apprehend the facts of city India this is extra than 11600 years antique.

\section{RISKS AND TRAUMATIC CONDITIONS TO MARINE TOURISM IN INDIA.}

unluckily the wonderful and safety of water sports activities sports available within the beaches of India are questionable. The water sports activities sports sports activities are usually operated thru the usage of the indigenous population with out an entire lot trouble for safety of the vacationers. The sports equipments and safety gears are not in suitable order. the supply of lifestyles guards is likewise very limited at the seashores.

The marine and coastal tourism is in particular at risk of climate trade, natural screw ups and pollution. the ocean degree upward thrust predicted from weather alternate is the most important long-term chance handling the tourism business enterprise in which maximum tourism infrastructure lies simply above sea level.

inside the short time period, unmanaged mass tourism can negatively impact coastal ecosystems. An critical fall out of unorganized and unregulated tourism in maximum of these beaches is pollution. Plastic and different wastes are allowed to be scattered on the beaches making them now not best unpleasant to the eyes however additionally bring about unfold of toxicity.

launch of bunker and oil spills has destroyed the ecology of many seashores which in numerous factors are characterised via using dirty water and beach remnants. criminal sports activities sports, prostitution and narcotics are a few other risk everyday on beaches particularly in Goa and Mumbai.

currently passenger cruise has began running at the Arabian coastline of India among Mumbai and Goa. Time will suggest if there are any fall outs that want to be taken into consideration.

protection and protection is one of the primary worries in terms of the prevailing coastal and river cruise machine of India. The boats used for close by cruise from Dwarka to guess Dwarka are operated with the aid of the indigenous youngsters, essentially untrained, semi expert, following no high-quality safety or protection code. The boarding jetty might be very unstable. people are pushed onto the boats like cattle which cruise on over capacity. No life jackets or protection equipments are provided to the passengers for this 30 minute trip at the Arabian sea with high waves and an less expensive intensity. it's miles high-quality and an hassle of exceptional troubles how the government are permitting such irregularities on the seashores of Gujarat.

The boat cruises from Gateway of India Mumbai to the Elephanta islands also aren't following strict protection and safety strategies at the same time as boarding as well as at some degree inside the hour cruise. The boats aren't very strong operated via the nearby teenagers who're semi expert. The boat cruises at the Arabian sea with immoderate waves and large depth. There are numerous boat cruises running inside the Andamans most of the islands. protection and protection are a chief situation there too. The Chilka lake is an inland lake related to the sea in Odisha. Boats ply tourists in this deep lake. pretty 0 safety norms are discovered right 
here by using the usage of the indigenous operators who also are semi professional. No lifestyles jackes are supplied to the passengers. The lake can be very deep. The boats are slender and don't have any safety device on board.

it's far indeed sudden that there can be minimal implementation of laws, guidelines and regulations within the cruise agency of India in which boat ferries transfer large form of tourists each Indian and foreigners alongside severa components of the coast as well as lakes and rivers of India just like the Ganges, Brahmaputra, Yamuna and many others. it is absolutely surprising that beneath the nose of government there is blatant flouting of protection norms with out a movement plan in place. This isn't first-rate a assignment but a persisting danger to the marine enjoyment agency each coastal and inland waterways. The apathy of the authorities is obvious prima facie and the operators do no longer appear to have the financial well well worth to enhance the facilities. So at the give up of the day it's far the traveler who dangers his life within the backdrop of an revel in of adventure and thrill.

\section{FUNCTION OF GOVERNMENT OF INDIA IN PROMOTING MARINE TOURISM}

For selling cruise tourism, joint efforts of Ministry of Tourism and Ministry of shipping are required and could act because the catalyst. thus, a task pressure has been constituted with Secretary (Tourism) because the Chairman and Secretary (delivery) due to the truth the Co-chairman. The mission pressure includes representatives from the ports, Ministries of health, home Affairs, outside Affairs, Customs, CISF, Coastal States, and masses of others. And meets frequently and has formulated preferred working approach (SOP) to be followed with the resource of the usage of the diverse companies for dealing with of cruise ships. The mission pressure has reviewed the SOPs and up to date them into the SOP version 2 this is for use for the cruise season 2017-18.

The Ministry of Tourism presents crucial financial assist (CFA) to the vital government organizations for development of Cruise Tourism infrastructure. New Cruise Terminals had been advanced in Mumbai, Goa, Kochi and Chennai ports with monetary assistance from the Ministry of Tourism. improvement of Cruise Terminals and Cruise ships also are protected below the huge sales generating (LRG) scheme of the Ministry for assist.

The Ministry of Tourism gives crucial monetary assist (CFA) to the country Governments/Union Territories for improvement of traveler infrastructure and selling of tourism consisting of developing facilities for River Cruise. in the assembly chaired by way of way of manner of the Hon'ble excessive Minister on 21st June 2014, it became determined that the Ministry of transport and the Ministry of Tourism might at the same time discover the routes for wearing out cruise excursions on waterways and moreover take measures to boom critical infrastructure. for this reason, a strolling employer become constituted to examine the modalities of cruise tours connecting non secular locations and superb associated problems. introduction of 'specific Tourism Zones' anchored on specific motive vehicles (SPVs) in partnership with the States became announced inside the finances for 2017-18. Ministry of Tourism has formulated the guidelines for implementation of the brand new scheme in consultation with the kingdom Governments and personal area and is inside the manner of finishing other formalities earlier than launching the scheme.

to overcome 'seasonality' project in tourism and to promote India as a three hundred and sixty 5 days vacation spot, Ministry of Tourism has taken the initiative of identifying, diversifying, developing and selling location of interest tourism merchandise of the us like Cruise. The Indian government is aware about infrastructure inadequacies and has a vision and plan for vending of cruise tourism and increase sea arrivals to at least one. 2 million vacationers by the use of the use of 2030-31. Cruise terminals are beneath development at Goa, Cochin, Mumbai and Chennai and people can probably enhance the residence hospitality commercial enterprise organisation that is moreover developing infrastructure and offerings to help port city tours and domestic tourism.

\section{MARITIME INDIA SUMMIT 2016}

Maritime India Summit 2016 focussed on 'leveraging the lengthy coastline and herbal maritime blessings' and invigorating the ocean economic device through the Sagarmala venture, which makes a speciality of port-led improvement included with specific financial zones, smart cities, business parks, logistics hubs and shipping corridors. one of the awareness are as among the ones modified into the development of coastal and marine tourism along the 7,500 kilometers prolonged coastline, it without a doubt is dotted with pristine beaches, tranquil water fronts and picturesque island territories. those are domestic to mangrove forests, nesting internet internet web sites for sea turtles, sea grass beds, coral reefs and the adjacent waters are home to a diffusion of fish and mammals.

\section{JAIL COOPERATION WITHIN THE MARINE TOURISM ENTERPRISE}

legal hints and policies want to be in vicinity that permits you to make sure a right governance of the Marine Tourism industry. due to the fact the industry caters to a niche place, the triumphing legal recommendations need to be made region precise and up to date appreciating the unique dreams of the agency. no longer best should the legal guidelines be in area however maritime jail training in India must be unfold all through the regulation colleges of the us of america to create experts who can put in force the prison guidelines of the location with the desired skills units and capability.

\section{THE MANNER FORWARD}

numerous measures are being curious about the useful resource of the government to collect upon the coastal and inland waterways entertainment business employer. The government of India wishes to ask 
cooperation and participation from the BIMSTEC member states to construct upon the marine entertainment agency. Sagarmala may be covered with the BIMSTEC to understand this vision. The indigenous operators of river and coastal cruise need to be brought into the international mainstream of the marine entertainment company by using using developing focus of the operational efficiencies of the commercial enterprise, the tips, suggestions and strategies, the safety and safety worries and the manner notable to carry out at global necessities. India has large capability inside the marine enjoyment industry supplied required upgradation in capability building and operational requirements are resorted to with out masses wastage of time.

An audit of the winning centers needs to be undertaken on as-is wherein-is foundation. this may illustrate the massive gaps that exist in the modern-day-day systems and corrective measures can be taken to standardize the agency after which improve to worldwide requirements. This enterprise enterprise has been omitted via all governments regardless of its excessive capacity to boom the GDP of India. The extremely-contemporary government need to planned and located into impact the severa theoretical motion plans which might be only modern-day on paper in recent times. priority need to obtain to an effective audit of the marine enjoyment corporation, jail cooperation and crook functionality constructing in the enterprise, imposing protection measures with strict compliances and cooperation inner BIMSTEC member states.

\section{REFERENCES}

1. Bull Adrian, Coastal and Marine Tourism, Routledge 2014

2. https://www.iora.int/media/23919/cios-prof-attripresentation.pdf

3. http://tourism.gov.in/tourism-policy

4. https://www.maritimeinvest.in/cruise-shipping-andlighthouse-tourism-cat

5. https://www.gatewayhouse.in/blue-economy-global-common/

6. http://www.coastalwiki.org/wiki/Impact_of_tourism_in_coast al_areas:_Need_of_sustainable_tourism_strategy

7. https://epicureandculture.com/marine-tourism/

8. http://www.gdrc.org/uem/eco-tour/charter.html

9. https://sustainabledevelopment.un.org/index.php?page=view $\& n r=472 \&$ type $=13 \&$ menu $=243$

10. Rajasekar D (2017). A study on motivation level of employees in automobile industry, International journal of Mechanical engineering and technology, 8(12), pp744- 749.

11. Rengamani.J, A Study On The Marine Engineers Retention Strategy by The Shipping Companies In India, International Journal of Production Technology and Management (IJPTM), 9(2), 2018, pp. 23-30.

12. Rengamani.J, Impact of Goods and Services Tax (GST) on the Shipping Companies in Chennai Sector, International Journal of Mechanical Engineering and Technology, 9(8), 2018, pp. 827-835.

13. Shrivastava A., Tourism Planning and Management, Centrum Press 2012

14. Vettriselvan, R., Antony Jesu Rajan, F. S. A., \& Arunkumar, N. (2019). Occupational health issues faced by women in spinners. Indian Journal of Public Health Research and Development, 10(1), 500-504.

15. Vettriselvan R., Sathya M., \& Velmurugan T. (2018), Productivity and Profitability Mechanical Engineering Entrepreneurs: Business Perspective, International Journal of Mechanical Engineering and Technology, 9(8): 758-765.

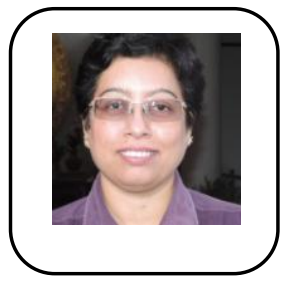

Madhumita Kothari is a Research Scholar in Maritime Studies at AMET Business School, AMET University Chennai. She is an International lawyer, a practicing Advocate \& Managing Partner of Juris International. She is an LL.M. with distinction from UK in Shipping Laws and a PGD gold medalist in International Laws.

Besides she also has her Masters in Management \& Geography. She has studied Law in India, Germany and United Kingdom with specialization in International Commercial Arbitration and Shipping Laws. She is a keynote speaker in various international conferences and she has been presenting various conference papers in her areas of expertise globally. She has received various national \& international awards like Bharat Gaurav Ratna (Pride of India) award for excellence in Maritime Studies, International Women Achiever's Award and Kala Samman Award as a legal luminary. Some of her notable publications include Rule of Law \& Belt \& Road Initiative, Enforcement of International Arbitral Awards \& Public Policy in India, Legal Cooperation within BIMSTEC \& BRI Connectivity. Her important international conference papers include: India, a cost effective destination for International Commercial Arbitrations: paper presented at the conference of International Council of Jurists, in London, presided over by the President International Court of Justice, HE Mr. Peter Tomka, June 2014, Enforcement of Arbitration Awards in India: paper presented at the conference of the International Council of Jurists in New Delhi, India in 2013, Need for a Better Human Rights Management in Asia: paper presented on the occasion of UN @ 70 an international conference at Amity University, Noida India 2017, Dispute Resolution under Law of the Sea Convention 1982: Gujarat National Law University Sep 2018, Role of Port State Control in elimination of substandard shipping: Gujarat National Law University Sep 2018, The necessity of General Average in Shipping : Gujarat National Law University Sep 2018, Increasing effectiveness of Port State Control to eliminate substandard Shipping : Central University of Gujarat Feb 2019, Rule of Law in the backdrop of BRI Connectivities : Central University of Gujarat March 2019, Rule of Law and BRI : CCAS Conference in IIC April 2019.

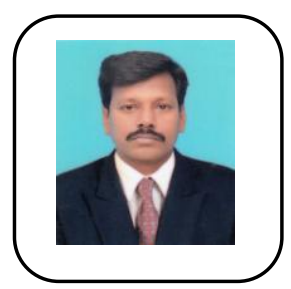

Dr.S.Poongavanam working as a Professor in AMET Business School, Academy of Maritime Education and Training (AMET) Deemed to be University. He done his Doctorate degree in Bharathidasan University. So far he has published nearly 127 articles in Scopus indexed/UGC approved journals and other indexed journals. He participated and presented 25 papers in international conference/seminar. He got five awards from reputed institutions. He is member of editorial board in seven international journals. 